\title{
ISOLATION OF THE PHOTOSYSTEM II REACTION CENTER COMPLEX FROM BARLEY. CHARACTERIZATION BY CIRCULAR DICHROISM SPECTROSCOPY AND AMINO ACID SEQUENCING
}

by

URSULA G. HINZ

Department of Physiology, Carlsberg Laboratory, Gamle Carlsbergvej 10, DK-2500 Copenhagen-Valby

Keywords: Amino acid sequence homology, Chl-proteins, lipid content, low temperature fluorescence emission, polypeptide composition, secondary structure, SDS-PAGE

A photosystem II (PSII) reaction center complex containing $\mathrm{Chl}_{a}$-protein 2, $\mathrm{Chl}_{a}$-protein 3, cytochrome $\mathrm{b}_{5 s}$, the herbicide-binding polypeptide and the $33 \mathrm{kD}$ polypeptide from the oxygen-evolving site of PSII was isolated by sucrose gradient centrifugation of the dodecyl- $\beta$,D-maltoside extract of grana membranes highly enriched in PSIl. The reaction center complex contained ca 19 lipid molecules per reaction center and sedimented slightly faster than catalase. It mediated light-induced, DCMU-sensitive electron transport from 1,5-diphenylcarbazide to dichlorophenolindophenol.

The $\mathrm{N}$-terminal amino acid sequence of a proteolytic fragment of $\mathrm{Chl}_{\alpha}$-protein 2 was determined. Eighteen out of 20 amino acid residues were identical with the deduced amino acid sequence of the $51 \mathrm{kDChl}_{a}$-apoprotein from spinach.

In contrast to grana membranes, which had a $77 \mathrm{~K}$ fluorescence emission maximum at $685 \mathrm{~nm}$ with a pronounced shoulder at $695 \mathrm{~nm}$, the PSII reaction center complex had a single peak at $685 \mathrm{~nm}$. Circular dichroism measurements in the visible range showed that the pigments associated with the isolated PSII reaction center complex and the light-harvesting complex (LHC) were highly oriented. The secondary structure of the PSII reaction center complex and LHC was investigated by circular dichroism measurements in the ultraviolet range. Both had a high $\alpha$-helix content, suggesting that the chlorophyll molecules may be oriented between transmembrane helices in a similar way as in bacterial reaction centers and light harvesting systems.

\section{INTRODUCTION}

Over the last seven years many different PSII preparations with varying degrees of complexity have been described. Preparations of grana membranes highly enriched in PSII by phase partitioning $(1,20)$ or Triton-treatment $(7,30)$ made it possible to study the function of PSII in a system which was close to the in vivo situation and to investigate the lateral distribution of proteins and lipids in the thylakoid membrane. Additionally, grana membranes were fractionated by extraction with various detergents fol-

Abbreviations: $\mathrm{Chl}=$ chlorophyll; $\mathrm{DCMU}=3$-(3,4-dichlorophenyl)-1,1-dimethylurea; DCPIP $=2,6$-dichlorophenolindophenol; DPC $=1,5$-diphenylcarbazide; $H E P E S=N$-(2-hydroxyethyl)-piperazine- $N$ '-2-ethane sulfonic acid; LHC = light harvesting complex; LHCII = LHC of photosystem II; PAGE = polyacrylamide gel electrophoresis; PS = photosystem; PTH = phenylthiohydantoin; SDS = sodium dodecyl sulfate; tricine $=$ $\mathrm{N}$-(tris(hydroxymethyl)methyl)glycine; Tris = tris-(hydroxymethyl)aminomethane. 
lowed by column chromatography, sucrose gradient centrifugation or isoelectric focussing (17, $38,39,46,49)$. Unfortunately many of these procedures were rather time-consuming or gave only low yield. With one exception (17), the lipid content of the preparations was not investigated.

The genes of proteins involved in photosynthetic electron flow are generally highly conserved as exemplified by the $32 \mathrm{kD}$ herbicidebinding polypeptide. The nucleotide sequence of this gene has been determined in a variety of organisms, showing very few differences between cyanobacteria (13), Chlamydomonas(15) and higher plants (50). The sequence of the D2 membrane polypeptide from PSII is also conserved $(3,22,37)$. The few differences occurring in the sequences of these polypeptides suggest that their tertiary structure and the architecture of the PSII core complex with which they interact may be equally conserved.

The molecular architecture of bacterial reaction center complexes has been the subject of numerous investigations. Recently the reaction center complex from a photosynthetic bacterium has been crystallized and its structure analysed at $3 \AA$ resolution, displaying transmembrane $\alpha$-helices and the organization of the pigments $(14,28)$. The structure of PSI and LHCII from higher plants has been studied by circular and linear dichroism spectroscopy, indicating the existence of transmembrane $\alpha$-helices slightly tilted relative to the membrane normal and an extremely low content of $\beta$-structure $(9$, $31,32)$. In contrast, very little is known about the structure of the PSII reaction center complex in higher plants.

We describe here the isolation of a functional PSII reaction center complex containing 5 polypeptides and ca 19 lipid molecules by a fast and simple method. The secondary structure of this reaction center complex and the organization of its pigments were investigated by circular dichroism measurements and compared with the bacterial system.

\section{MATERIALS AND METHODS}

\subsection{Biological preparations}

Wild type barley seedlings (Hordeum vulgare cv Svalöfs Bonus) were grown for 7 days in vermiculite under continuous illumination (1700 lux). The mutant chlorina- $f 2$ was grown under the same conditions. Mutant and wild type thylakoids were prepared for SDS-PAGE as described in (25). Grana membranes were prepared using a modification of the Triton X-100 method of BERTHOLD et al. (7) as described in (30).

\subsection{Isolation of the PSII reaction center complex}

For the isolation of the PSII reaction center complex grana membranes were solubilized by

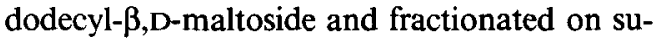
crose gradients in a similar way as described in (47). The membranes were diluted to a final concentration of $1 \mathrm{mg} \cdot \mathrm{ml}^{-1}$ chlorophyll in a buffer containing $20 \mathrm{mM}-\mathrm{HEPES}, 200 \mathrm{~mm}$ $\mathrm{NaCl}, 1$ mM-EDTA, pH 8.0. Ten mg dodecyl-

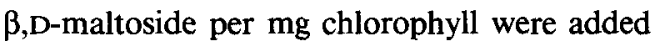
and the sample was incubated for $10 \mathrm{~min}$ at room temperature. All further steps were performed at $4{ }^{\circ} \mathrm{C}$. The sample was centrifuged for $10 \mathrm{~min}$ at $16.000 \mathrm{~g}$ to pellet insoluble material. The supernatant was applied to gradients containing $10-30 \%$ sucrose, $0.02 \%$ Triton $\mathrm{X}-100,10$ $\mathrm{mM}$-Tricine, $\mathrm{pH}$ 8.0. After $24 \mathrm{~h}$ centrifugation at $83.000 \mathrm{~g}$ fractions were collected from the top. Material which was not used immediately was frozen rapidly in liquid nitrogen and stored at $-30^{\circ} \mathrm{C}$.

\subsection{Spectroscopic measurements}

Absorption spectra were recorded using an Aminco DW2a spectrophotometer. The concentration of the samples was adjusted to an absorbance of ca 0.3 at $670 \mathrm{~nm}$.

Fluorescence emission spectra at liquid nitrogen temperature were measured using a fiber optic system (Applied Photophysics, London, England) as described in (41).

Room temperature circular dichroism spectra were obtained on a Roussel-Jouen Dichrograph III. The length of the optical cell was $1 \mathrm{~cm}$, enabling us to take spectra of dilute samples.

For measurements in the ultraviolet range (200-260 nm) sucrose was removed from the gradient fractions by gel-filtration over an AcA 
34 column equilibrated in $0.02 \%$. Triton X-100, 10 mM-Tricine, $\mathrm{pH} 8.0$.

\subsection{Electron transport measurements and de- termination of cytochrome content}

PSII activity was determined as DCMU-sensitive photoreduction of DCPIP by following the rate of decrease of the absorbance at $575 \mathrm{~nm}$ using 1,5-diphenylcarbazide as electron donor.

The cytochrome content was determined from reduced minus oxidized difference spectra as described in (30).

\subsection{Lipid analysis}

Ten volumes of chloroform : methanol (1:1 $\mathrm{v} / \mathrm{v}$ ) were added to each of the samples in a teflon lined screw cap tube. After vortexing vigorously for $3 \mathrm{~min}, 2$ volumes of $25 \% \mathrm{NaCl}$ were added and the chloroform phase pipetted off. Two additional extractions with 2 volumes of chloroform were made. The combined chloroform extracts were dried over anhydrous $\mathrm{Na}_{2} \mathrm{SO}_{4}$, passed through a cotton plug in a Pasteur pipette into a clean screw cap tube and taken to dryness under a stream of nitrogen. After the addition of 206 nmoles of pentadecanoic acid the lipids were transesterified using $3 \mathrm{ml}$ of $14 \% \mathrm{BF}_{3}$ in methanol and heating for $20 \mathrm{~min}$ at $80^{\circ} \mathrm{C}$.

Cooling and dilution with $2 \mathrm{ml}$ water plus 2.5 $\mathrm{ml} 25 \% \mathrm{NaCl}$ were followed by 3 extractions of the solution with $2-3 \mathrm{ml}$ hexane. After the removal of hexane under a stream of argon at $20^{\circ} \mathrm{C}$ or less, aliquots in hexane were analyzed by gas chromatography using a $10 \%$ Silar $10 \mathrm{C}$ column (5) in a Hewlett Packard Model 5840A instrument. The column temperature was held at $150^{\circ} \mathrm{C}$ for $5 \mathrm{~min}$ before heating at $3^{\circ} \cdot \mathrm{min}^{-1}$ to $200^{\circ} \mathrm{C}$. Injector and detector temperatures were 220 and $350{ }^{\circ} \mathrm{C}$, respectively. To allow for quantitation, calibration was carried out as described in (35) with methyl pentadecanoate, methyl palmitate and methyl stearate from Applied Science (Oud-Beijerland, Holland). The flame ionization detector response factors given in (42) were used.

\subsection{Electrophoresis}

One $\mathrm{mm}$ thick SDS-polyacrylamide gels containing 12.5 or $15 \%$ polyacrylamide were used for both analytical and preparative purposes. The gels were run at $4{ }^{\circ} \mathrm{C}$ using buffer system II (25). The samples were solubilized using $10 \mathrm{mg}$

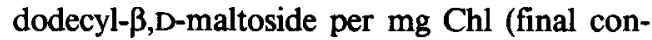
centration $1 \%$ ) and the SDS concentration in the gels was lowered to $0.03 \%$ to minimize pigment loss. Proteins were visualized by staining with Coomassie Brilliant Blue R250 or by the alkaline silver stain described in (48).

For the isolation of $\mathrm{Chl}_{a}$-protein 2 and $\mathrm{Chl}_{\alpha}$ protein 3 by preparative SDS-PAGE chlorina- 2 thylakoids were used as the starting material to avoid contamination by oligomers of LHCII. The bands containing $\mathrm{Chl}_{a}$-protein 2 and $\mathrm{Chl}_{a}$ protein 3 were cut out from unstained gels. The gel slices were ground using a glass rod in a Nunc Minisorp test tube and incubated for $12 \mathrm{~h}$ at $4{ }^{\circ} \mathrm{C}$ with five volumes of distilled water. This extraction step was repeated with $0.05 \%$ SDS in distilled water. Polyacrylamide fragments were removed by centrifugation. The supernatants were lyophilized and redissolved in a small volume of distilled water.

Proteolytic digestion with Staphylococcus aureus protease V8 (Miles Laboratories) was performed during SDS-PAGE as described in (11). Purified $\mathrm{Chl}_{a}$-protein 2 was applied to a $15 \%$ polyacrylamide gel, together with increasing amounts of protease $(0.1-10 \% \mathrm{w} / \mathrm{w})$. These gels were run without cooling. They were stained with Coomassie Brilliant Blue R250. Bands containing 5-20 $\mu \mathrm{g}$ material were excised and the peptides were eluted with $70 \%$ formic acid as described in (40) or with 50\% acetic acid. Formic acid (70\%) is a better solvent for peptides than acetic acid $(50 \%)$, but has the disadvantage that it tends to react with their free $\mathrm{N}$-termini. The eluted material was dried under vacuum. The peptides were redissolved in $60 \mu 170 \%$ formic acid and separated from buffer components and other low molecular weight compounds by gel filtration on a $30 \mathrm{~cm}$ long Sephadex G50 column (column volume $2 \mathrm{ml}$ ) equilibrated in the same solvent. The peptide-containing fractions were lyophilized after the addition of $40 \mu 10.1 \%$ SDS. They were redissolved in $40 \mu$ l distilled water and applied to a gas-phase protein sequencer (Applied Biosystems 470 A). PTH-amino acids were identified by HPLC. 


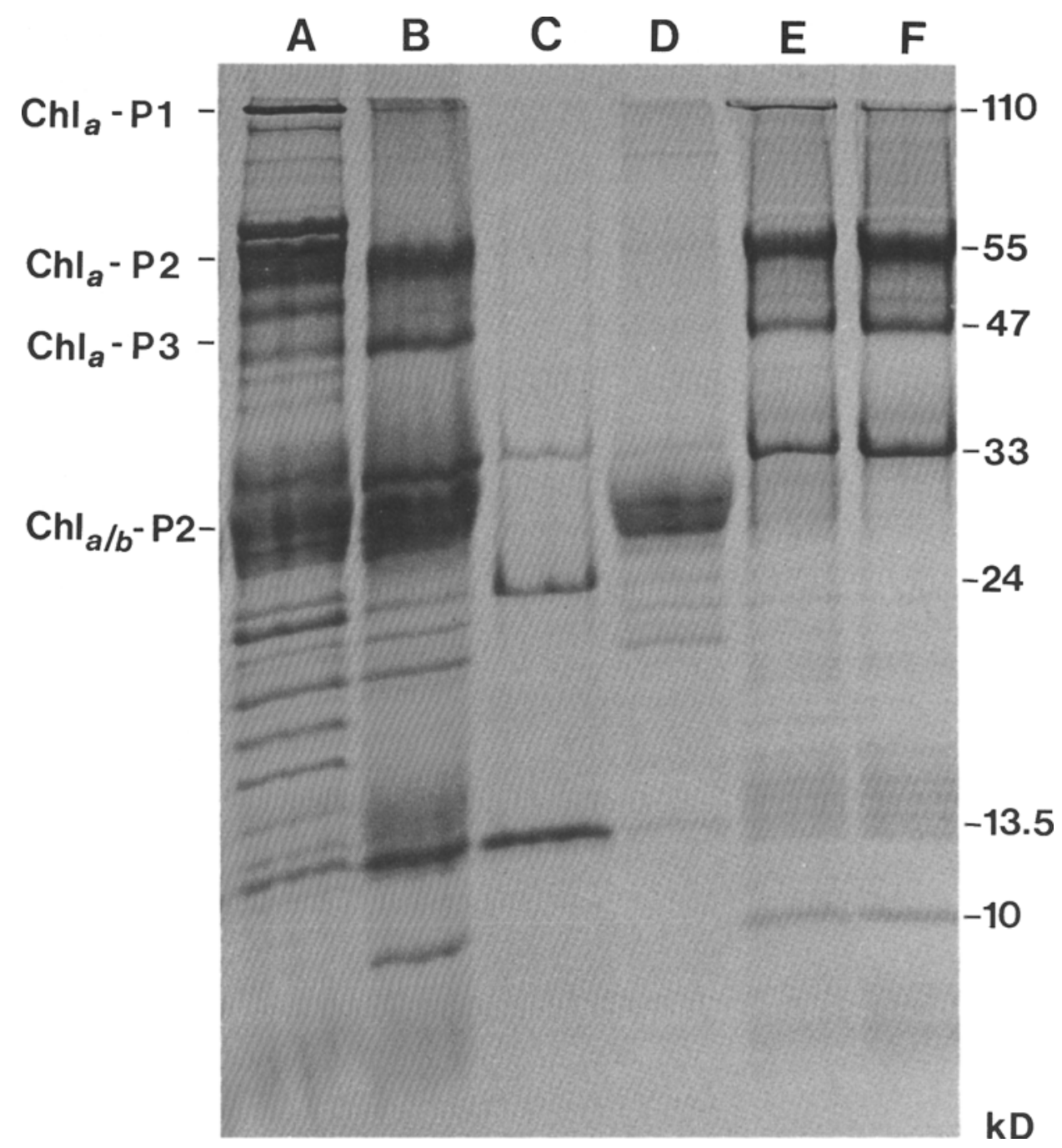

Figure 1. Polypeptide composition of the preparations as revealed by SDS-PAGE. Gels containing $12.5 \%$ polyacrylamide were run at $4^{\circ} \mathrm{C}$ and stained with Coomassie Brilliant Blue. A: thylakoids. B: dodecyl- $\beta, D-$ maltoside extract of grana membranes. C-F: gradient fractions. C: salt-releasable polypeptides. D: LHCII. E: aliquot from the region between the two green bands. F: PSII reaction center complex.

\subsection{Other methods}

The chlorophyll concentration was measured in $80 \%$ acetone according to the method of ARNON (4). Protein was quantitated as described by LOWRY et al. (24), using bovine serum albumin as a standard. The amino acid composition of the proteins was determined after $24 \mathrm{~h}$ hydrolysis at $108{ }^{\circ} \mathrm{C}$ in $6 \mathrm{~N}-\mathrm{HCl}$ in evacuated, sealed tubes.

\section{RESULTS}

\subsection{Isolation of the PSII reaction center complex}

A functional PSII reaction center complex was prepared by sucrose gradient centrifugation of dodecyl- $\boldsymbol{\beta}, \mathrm{D}$-maltoside extracts of grana membranes highly enriched in PSII. The polypeptide composition of the different fractions is shown in Figure 1. The colourless fraction at the 
U.G. HINZ: Photosystem II reaction center complex

Table I.

Characteristics and yield of fractions obtained during the isolation of the PSII reaction center complex.

\begin{tabular}{lccccc}
\hline Fraction & $\begin{array}{l}\text { chlorophyll } \\
(\mathrm{mg})\end{array}$ & $\begin{array}{l}\text { protein } \\
(\mathrm{mg})\end{array}$ & $\begin{array}{l}\text { Chl } \\
a / b\end{array}$ & $\begin{array}{l}\text { protein/ } \\
\text { Chl }\end{array}$ & $\begin{array}{l}\mu \text { moles DCPIP/ } \\
\mathrm{h} \cdot \mathrm{mg} \mathrm{Chl}\end{array}$ \\
\hline $\begin{array}{l}\text { Thylakoids } \\
\text { Grana membranes }\end{array}$ & 215 & 2580 & 2.9 & 12 & 8.7 \\
$\begin{array}{l}\text { Dodecyl-maltoside } \\
\text { extract }\end{array}$ & 63 & 630 & 2.3 & 10 & nd \\
LHCII & 50 & 500 & 2.3 & 10 & 44 \\
PSII reaction & 44.5 & 405 & 1.6 & 9.1 & $\mathrm{nd}$ \\
center complex & 5.5 & 42 & 9.3 & 8.7 & 36 \\
\hline
\end{tabular}

nd: not determined

top of the gradient contained equal amounts of the two salt-releasable polypeptides with apparent molecular weights $24 \mathrm{kD}$ and $13.5 \mathrm{kD}$ plus traces of a $33 \mathrm{kD}$ polypeptide. The association of these polypeptides with the oxygen-evolving system and their release by high salt or alkaline Tris has been described by several authors $(1,30$, $46,49)$.

The upper deep green band containing LHCII had a Chl $a / b$ ratio of 1.6 (Table I), while that of the lower green band containing the PSII reaction center complex ranged from 8 to 10 . The PSII reaction center complex contained $\mathrm{Chl}_{a}$ protein 2, $\mathrm{Chl}_{a}$-protein 3 , cytochrome $b_{5 s 9}$, the herbicide-binding polypeptide and at least one more polypeptide in the $33 \mathrm{kD}$ region (Figure 1 ). The $10 \mathrm{kD}$ band may represent the apoprotein of cytochrome $b_{559}$. The faint band comigrating with $\mathrm{Chl}_{a}$-protein 1 was probably a protein aggregate since the extract was strongly depleted in PSI. The herbicide-binding polypeptide did not stain with Coomassie Brilliant Blue or silver. Its presence was deduced from the observation that electron transport through the PSII reaction center complex was fully sensitive to DCMU. The $33 \mathrm{kD}$ polypeptide stained well with Coomassie Brilliant Blue. When its amino acid composition was determined (Table III), it was found to contain lysine, indicating that this 33 $\mathrm{kD}$ polypeptide is not related to the quinonebinding polypeptide of similar size since the latter is completely deficient in lysine (50). The amino acid compositions of the $33 \mathrm{kD}$ polypeptide associated with the PSII reaction center complex and of the $32 \mathrm{kD}$ polypeptide from the oxygen-evolving system described in (30) are similar, indicating that they are one and the same polypeptide. Except for the low potential form of cytochrome $b_{559}$, no other cytochromes were detected by reduced minus oxidized difference spectra. During sucrose gradient centrifugation the PSII reaction center complex sedimented as a sharp band and slightly faster than catalase $(250 \mathrm{kD})$, indicating that it was composed of particles homogeneous in size and not of membrane fragments.

Measurements of light-induced electron transport from DPC to DCPIP are summarized in Table I. The PSII reaction center complex showed higher rates of electron transport than thylakoids on a $\mathrm{Chl}$ basis because of the removal of Chl associated with LHC and PSI. The isolated PSII reaction center complex was fully sensitive to DCMU.

Absorption spectra of the PSII reaction center complex and LHCII are shown in Figure 2. The PSII reaction center complex had an absorption maximum at $671 \mathrm{~nm}$. In the case of LHCII this peak was shifted to $670 \mathrm{~nm}$ and had a shoulder at $652 \mathrm{~nm}$ due to $\mathrm{Chl} b$. The absorption spectrum of LHCII had an absorption maximum at $467 \mathrm{~nm}$ reflecting its high content of $\mathrm{Chl} b$ and carotenoids. The spectrum of the PSII reaction center complex has a shoulder in this region, showing that it does contain small amounts of carotenoids.

The $77 \mathrm{~K}$ fluorescence emission spectra of grana membranes, the PSII reaction center com- 


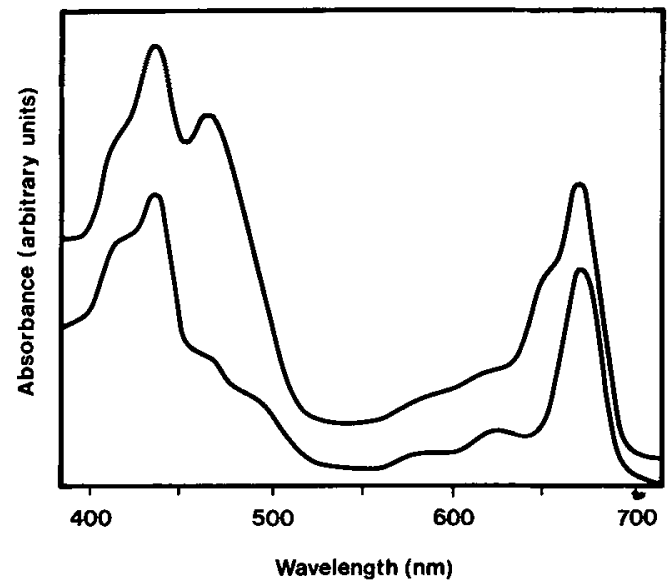

Figure 2. Absorbance spectra of the PSII reaction center complex (bottom) and LHCII (top). The samples were adjusted to an absorbance of ca 0.3 at 670 $\mathrm{nm}$. The spectrum of LHC is shifted upwards relative to that of the PSII reaction center complex to allow details of both spectra to be seen clearly.

plex and LHCII are shown in Figure 3. Grana membranes had a fluorescence emission maximum at $685 \mathrm{~nm}$ with a pronounced shoulder at $695 \mathrm{~nm}$. There was very little fluorescence at longer wavelengths, where pigments associated with PSI emit (41). The PSII reaction center

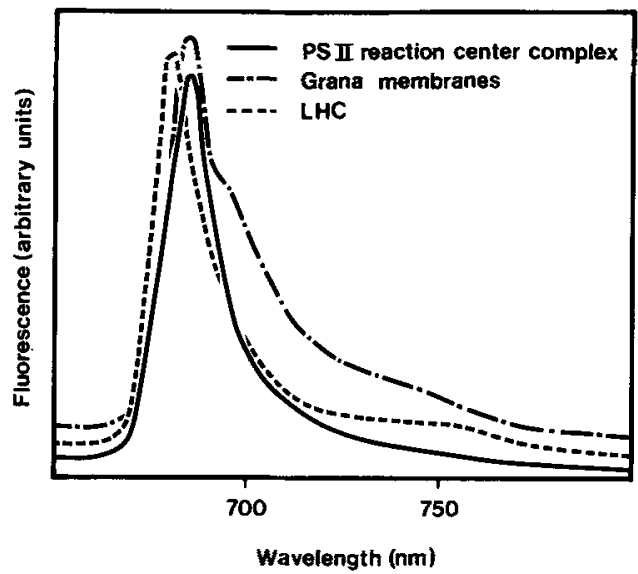

Figure 3. Low temperature ( $77 \mathrm{~K}$ ) fluorescence emission spectra of grana membranes, the PSII reaction center complex and LHCII.

complex had a fluorescence maximum at 685 $\mathrm{nm}$ without a shoulder at $695 \mathrm{~nm}$. The fluorescence maximum of LHCII was at $680 \mathrm{~nm}$.

\subsection{Lipid content of grana membranes and the PSII reaction center complex}

Lipids were quantitated as fatty acid methyl esters after hydrolysis with $\mathbf{B F}_{3}$. The results are

Table II.

Lipid analysis.

\begin{tabular}{|c|c|c|c|c|c|c|c|c|}
\hline \multirow[t]{2}{*}{ Fraction } & \multirow{2}{*}{$\begin{array}{l}\text { «mole lipid/ } \\
\text { mg Chl } a\end{array}$} & \multirow{2}{*}{$\begin{array}{l}\text { nmole lipid/ } \\
\text { mg protein }\end{array}$} & \multicolumn{6}{|c|}{ Fatty acid distribution (mole \%) } \\
\hline & & & $16: 0$ & $16: 1$ & 18:0 & $18: 1$ & $18: 2$ & $18: 3^{\text {a) }}$ \\
\hline \multirow[t]{3}{*}{ Thylakoids } & 5.5 & 389 & 9.5 & 1.8 & 0.4 & 0.9 & 5.8 & 81.7 \\
\hline & 5.1 & 360 & 9.3 & 1.9 & 0.4 & 1.0 & 5.7 & 81.8 \\
\hline & 5.9 & 416 & 8.3 & 1.7 & 0.3 & 0.8 & 5.5 & 83.3 \\
\hline \multirow{4}{*}{$\begin{array}{l}\text { Grana } \\
\text { membranes }\end{array}$} & 1.4 & 76 & 20.6 & 3.7 & 2.4 & 2.4 & 9.0 & 61.9 \\
\hline & 1.3 & 75 & 20.6 & 3.7 & 2.5 & 2.3 & 9.2 & 61.7 \\
\hline & 1.2 & 67 & 20.9 & 3.7 & 2.6 & 2.6 & 9.2 & 61.1 \\
\hline & 0.9 & 61 & 22.4 & 3.6 & 3.5 & 4.3 & 10.6 & 55.5 \\
\hline \multirow{3}{*}{$\begin{array}{l}\text { PSII reaction } \\
\text { center complex }\end{array}$} & 0.6 & 50 & 23.6 & 6.4 & 3.2 & 4.7 & 7.2 & 54.9 \\
\hline & 1.0 & 80 & 21.5 & 5.5 & 4.1 & 5.3 & 9.7 & 54.0 \\
\hline & 0.6 & 56 & 24.2 & 5.1 & 1.7 & 5.9 & 12.6 & 50.5 \\
\hline
\end{tabular}

a) $16: 0=$ palmitic acid; $16: 1=$ hexadecanoic acid; $18: 0=$ stearic acid; $18: 1=$ oleic acid; $18: 2=$ linoleic acid; $18: 3=\alpha$-linoleic acid 
U.G. Hinz: Photosystem II reaction center complex

presented in Table II. Thylakoids contained 5.5 $\mu$ mole acyl lipids per mg Chl $a$, or 390 nmole lipid per mg protein. Grana membranes prepared by Triton-treatment had only $20 \%$ of the lipid content of thylakoids relative to $\mathrm{Chl}$ and protein. There were $1.24 \mu$ mole lipids per $\mathrm{mg}$ $\mathrm{Chl} a$ or $72 \mathrm{nmole} \mathrm{lipid} \mathrm{per} \mathrm{mg} \mathrm{protein.} \mathrm{The} \mathrm{PSII}$ reaction center complex contained an average of $0.7 \mu$ mole lipid per mg Chl $a$ or 62 nmole lipid per mg protein, indicating that there was a core of tightly bound lipids which were not removed by detergent extraction and sucrose gradient centrifugation. $\alpha$-Linoleic acid $\left(C_{18: 3}\right)$ was by far the most abundant fatty acid in thylakoids. During purification the amount of $\alpha$-linoleic acid (mole \%) decreased from $82 \%$ in thylakoids to $55 \%$ in the PSII reaction center complex and the amount of palmitic acid $\left(\mathrm{C}_{16: 0}\right)$ increased from 9 to $22 \%$.

\subsection{Amino acid composition and sequence analysis}

In order to avoid contamination by oligomers of LHCII the $\mathrm{Chl}_{a}$-proteins 2 and 3 were prepared from the mutant chlorina- $f 2$ as described in 2.6. As the $\mathrm{N}$-terminus of $\mathrm{Chl}_{a}$-protein 2 was apparently blocked, the intact protein could not be used for amino acid sequence analysis. Instead, after partial proteolytic digestion of $\mathrm{Chl}_{\alpha}$ protein 2 with Staphylococcus aureus protease V8, three of the peptides with apparent molecular weights $11.5,9.9$ and $6.6 \mathrm{kD}$ were isolated by preparative SDS-PAGE. All three peptides had the same $\mathrm{N}$-terminal amino acid sequence (Figure 4), indicating that the 9.9 and the $6.6 \mathrm{kD}$ peptides were derived from the $11.5 \mathrm{kD}$ peptide by further cleavage in the C-terminal part of the molecule. The repetitive yield during sequencing was $88 \%$. Eighteen out of 20 amino acid residues in this sequence are identical with a part of the sequence deduced from the nucleotide sequence of the gene for the $51 \mathrm{kDChl}_{a}$-apoprotein from spinach, starting with residue 401 (29). At position 408 a glutamic acid residue has been replaced by glycine. The other change is conservative, asparagine in position 410 instead of serine. Moreover, the deduced amino acid sequence of the $51 \mathrm{kD} \mathrm{Chl}{ }_{a}$-apoprotein had a glutamic acid residue directly in front of the N-ter-

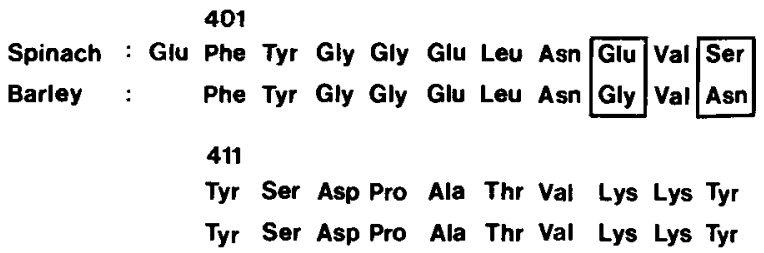

Figure 4. Sequence homology between the $\mathrm{N}$-terminal amino acids of the $9.9 \mathrm{kD}$ proteolytic peptide of $\mathrm{Chl}_{a}$-protein 2 from barley and a portion of the deduced amino acid sequence of the $51 \mathrm{kD} \mathrm{Chl}_{a}$-apoprotein from spinach starting at residue 401 .

minus of the analyzed peptides. This was expected because Staphylococcus aureus protease V8 cuts preferentially after glutamic acid residues. It also cuts after aspartic acid residues but with lower efficiency. The apparent molecular weights of the three proteolytic peptides were consistent with the positions of glutamic and aspartic acid residues in the sequence of the spinach $51 \mathrm{kD} \mathrm{Chl}_{a}$-apoprotein.

Table III lists the amino acid composition of $\mathrm{Chl}_{\alpha}$-protein 2, its $9.9 \mathrm{kD}$ proteolytic fragment and of $\mathrm{Chl}_{a}$-protein 3 . The amino acid compositions of the $51 \mathrm{kDChl}_{a}$-apoprotein and of the 44 $\mathrm{kD} \mathrm{Chl}{ }_{a}$-apoprotein from spinach which were deduced from the nucleotide sequence of their respective genes $(3,29)$ are shown for comparison. The amino acid composition of $\mathrm{Chl}_{a}$-protein 2 was similar to that of the $51 \mathrm{kDChl}_{a}$-apoprotein from spinach and the amino acid composition of $\mathrm{Chl}_{a}$-protein 3 resembles that of the $44 \mathrm{kD} \mathrm{Chl}_{a}$-apoprotein, suggesting that the proteins from barley and spinach are closely related.

The amino acid composition of $\mathrm{Chl}_{a}$-protein 2 and $\mathrm{Chl}_{a}$-protein 3 shows that both proteins are highly hydrophobic. They have 47.2 and $44.7 \%$ nonpolar amino acids respectively. A ratio of polar to apolar amino acids close to one is typical for integral membrane proteins whereas soluble proteins usually have a ratio of polar to apolar residues close to two $(10,18,19)$.

\subsection{Circular dichroism studies}

Ultraviolet circular dichroism spectra of gradient fractions containing the PSII reaction 
U.G. HINZ: Photosystem II reaction center complex

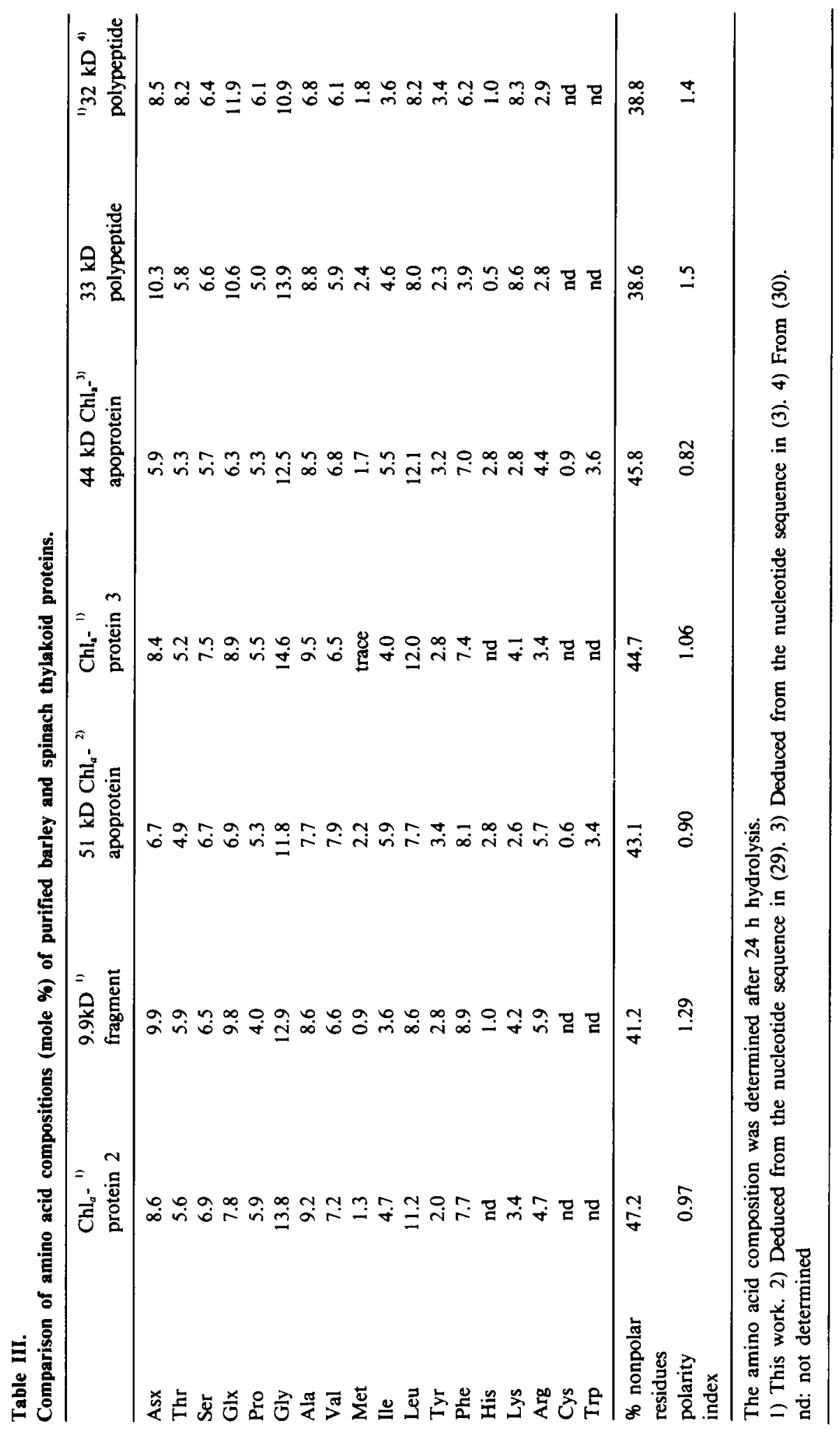




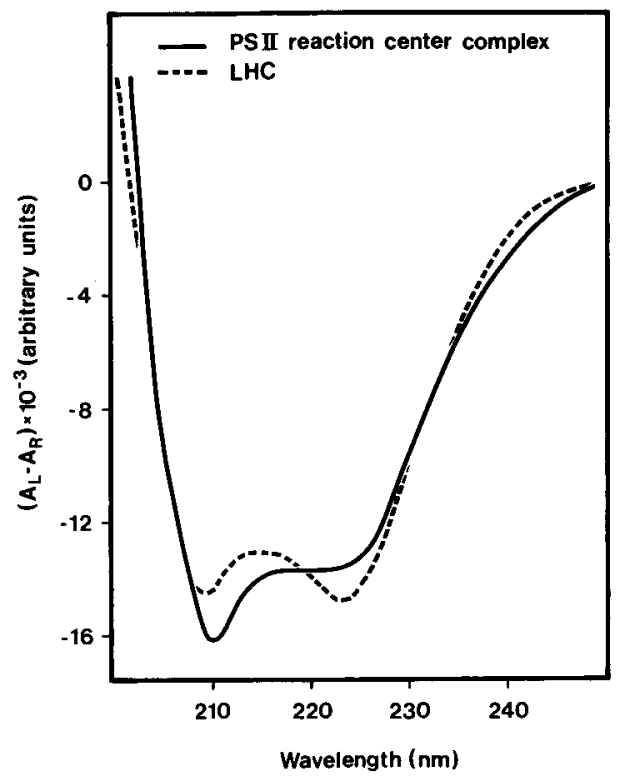

Figure 5. Ultraviolet circular dichroism spectra of the PSII reaction center complex and LHCII.

center complex and LHCII are shown in Figur 5. The shape of the curves indicates that both complexes have a high content of $\alpha$-helix. A broad trough with minima at $222 \mathrm{~nm}$ and 208 $\mathrm{nm}$ and an intersection with the baseline close to $200 \mathrm{~nm}$ is typical for $\alpha$-helical polypeptides. $\beta$-pleated sheet gives rise to spectra with a narrow, single trough with a minimum at 217 $\mathrm{nm}$. In the visible range the circular dichroism spectra of the two preparations differed markedly as shown in Figure 6. The split peak underlies the red absorption maximum of the PSII reaction center complex with a negative component at $686 \mathrm{~nm}$ and a positive component at $673 \mathrm{~nm}$. A small double trough in the region between 440 and $500 \mathrm{~nm}$ indicates that a few highly oriented carotenoid molecules are associated with the PSII reaction center complex. The positive circular dichroism signal at $409 \mathrm{~nm}$ is due to Chl $a$. The spectrum of LHC had two troughs in the red with minima at 689 and 657 $\mathrm{nm}$. The former signal can be attributed to $\mathrm{Chl}$ $a$, the latter to $\mathrm{Chl} b$. The strong circular dichroism signals between 440 and $500 \mathrm{~nm}$ indicates the existence of highly oriented species of Chl $b$ and carotenoids. Further investigations are needed to assign single peaks to discrete components as well as to explain the origin of the opposite signals at $438 \mathrm{~nm}$ of the two preparations. Upon denaturation by $4 \mathrm{M}$-guanidium chloride the circular dichroism signals of the PSII reaction center complex and of LHCII disappeared, showing that the spectra observed were not due to the intrinsic dichroism of the pigments, but to their organization in pigmentprotein complexes. The intrinsic dichroism signals of the pigments were too weak to be detected at the concentrations used.

\section{DISCUSSION}

A PSII reaction center complex from barley was isolated by a one step procedure using sucrose gradient centrifugation. Inclusion of 200 $\mathrm{mM}-\mathrm{NaCl}$ in the solubilization medium made it possible to omit washing of the membranes with high salt as a separate step. The Triton concentration in the gradients was lower than in (47) which is an advantage as high concentrations of this detergent were found to denature PSII. Dodecyl- $\beta$,D-maltoside extracts of grana membranes highly enriched in PSII were separated into the PSII reaction center complex, LHCII and salt-releasable polypeptides. In comparison with other methods for the preparation of PSII reaction center particles $(17,38,39,46$, 49) the one described here has the advantages of being fast, simple and giving high yield.

The PSII reaction center complex was functional since it mediated light-induced, DCMUsensitive electron transport from DPC to DCPIP. It contained at least five polypeptides: $\mathrm{Chl}_{a}$-protein 2, $\mathrm{Chl}_{a}$-protein 3, the herbicidebinding polypeptide, cytochrome $b_{559}$ and a 33 $\mathrm{kD}$ polypeptide. Most of the PSII reaction center complexes described retain a $33 \mathrm{kD}$ polypeptide although they are prepared by quite different methods $(17,46,49)$. Only when drastic procedures such as washing with alkaline Tris are used is it absent (47). The amino acid composition of the presently isolated $33 \mathrm{kD}$ polypeptide was essentially identical with that of the $33 \mathrm{kD}$ polypeptide from the oxygen evolving system described in (30). Very minor quantities of this $33 \mathrm{kD}$ polypeptide were found together with 

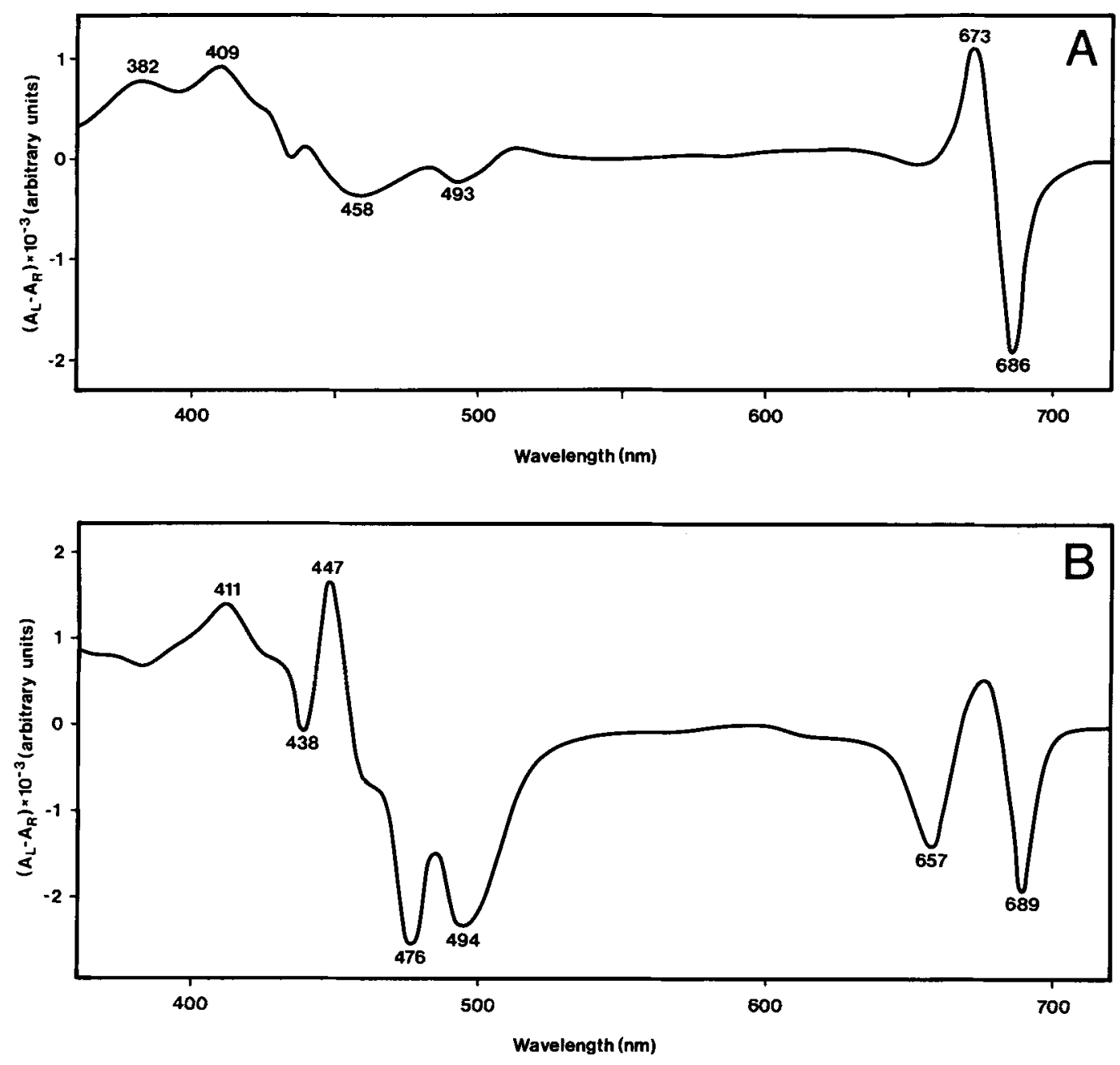

Figure 6. Visible range circular dichroism spectra of the PSII reaction center complex (A) and LHC (B).

the salt-releasable 24 and $13.5 \mathrm{kD}$ polypeptides at the top of the gradient, confirming that it interacts directly with the PSII reaction center complex and that it is tightly bound. The isolated polypeptides have no detected enzymatic activity, but they are assumed to stabilize manganese and other ions in the oxygen evolving system (2, 16, 49).

Very hydrophobic proteins, such as the Fo part of the membrane-bound ATPase, interact strongly with lipids and indeed lose activity when the lipids are completely removed (12). Since the PSII reaction center complex is com- posed of hydrophobic proteins, we analyzed the lipid content of the preparations. Grana membranes obtained by Triton-treatment contained half as much lipid as those obtained by phase partitioning as described in $(20,21)$. This was reasonable as no detergent is used in the phasepartitioning procedure. Despite this difference in lipid content both types of preparations appear as membranes in the electron microscope (30). The remaining lipids are sufficient to maintain the functional integrity of Triton-treated grana membranes, since MøLLER and HøJ (30) were able to measure the formation of proton 
gradients. The isolated PSII reaction center complex contained on the average $0.7 \mu$ moles lipid per $\mathrm{mg} \mathrm{Chl} a$ or 62 nmoles lipid per $\mathrm{mg}$ protein. This corresponds to a $11 \%$ reduction relative to Triton-treated grana membranes on a protein basis, and the preparation contained ca 19 lipid molecules per reaction center. These lipids were tightly bound and could not be removed without denaturation of the PSII reaction center complex. The lipids associated with the presently isolated PSII reaction center complex were enriched in palmitic acid $\left(\mathrm{C}_{16: 0}\right)$ and depleted in $\alpha$-linoleic acid $\left(\mathrm{C}_{18: 3}\right)$ with respect to the starting thylakoids. This observation is interesting in connection with the fatty acid composition determined for individual lipid classes from phase-partitioned grana membranes (21). That is, galactolipids had a very high content of $\alpha$-linoleic acid in contrast to the other lipid classes. This suggests that the decrease in lipids in the PSII reaction center complex is due to the preferential removal of galactolipids, as opposed to sulfolipids and phospholipids. This is in agreement with the finding that the enzymatic hydrolysis of phospholipids inhibits specifically PSII (23). All this indicates that lipids are an essential part of the PSII reaction center complex and that their composition is different from the overall lipid composition of grana membranes. The presence of these lipids makes it difficult, if not impossible, to obtain three-dimensional crystals of the functional PSII reaction center complex from barley and to analyze its structure and the organization of its pigments by X-ray diffraction, as has been described for a bacterial reaction center complex (14).

Spectroscopic procedures have been used to monitor the structural integrity of Chl-protein complexes and for their characterization. Grana membranes have a low temperature fluorescence emission maximum at $685 \mathrm{~nm}$ with a shoulder at $695 \mathrm{~nm}$. This fluorescence at 695 $\mathrm{nm}$ has been attributed to the reaction center of PSII itself $(8,33,34,45)$. The fluorescence at $685 \mathrm{~nm}$ was thought to arise from $\mathrm{Chl} \mathrm{mol-}$ ecules with a light-harvesting function. The presently isolated reaction center complex had a fluorescence emission maximum at $685 \mathrm{~nm}$ without a shoulder at $695 \mathrm{~nm}$. Since this prep- aration was active, it is concluded that the fluorescence at $685 \mathrm{~nm}$ has contributions both from the reaction center itself and from antenna Chl molecules within the same complex. The fluorescence at $695 \mathrm{~nm}$ may reflect the aggregation state of the Chl-protein complex. Aggregation or treatment with cupric phenanthroline can shift the fluorescence emission to longer wavelengths $(33,34,45)$. Cupric phenantroline catalizes protein crosslinking via disulfide bridges $(43,44)$ and may thereby cause aggregation.

Circular dichroism studies in the visible range confirmed that the pigment molecules associated with the PSII reaction center complex and with LHCII retained a high degree of organization during the purification procedure. The circular dichroism of the isolated, functional PSII reaction center complex from higher plants has not been previously investigated. It has a split peak underlying the red absorption maximum of $\mathrm{Chl}_{a}$, a feature also found in the reaction center of PSI (32) and in bacterial reaction centers (26), but not in LHC. This is thought to be due to exciton interaction between two closely associated Chl molecules (26), and the existence of such a pair in a bacterial reaction center complex has been demonstrated by crystallographic analysis (14). The spectrum of the intact PSII reaction center complex was simpler than that of $\mathrm{Chl}_{a}$-protein 2 and $\mathrm{Chl}_{a^{-}}$ protein 3 isolated by preparative SDS-PAGE (6), perhaps due to contamination of the latter by LHC I-730.

Ultraviolet circular dichroism spectra of the presently isolated PSII reaction center complex and LHCII showed that their secondary structure had a high content of $\alpha$-helix. Similar results have been described for isolated PSI particles and $\operatorname{LHC}(9,31,32)$, indicating up to $50 \%$ $\alpha$-helix and maximally $10 \% \beta$-pleated sheet. Our results are in agreement with the prediction of a high content of $\alpha$-helix for thylakoid membrane proteins based on the circular dichroism of sonicated thylakoid membranes (36). A high content of $\alpha$-helix seems to be typical for Chlproteins, also for those from photosynthetic bacteria. So far, only one exception is known, a water-soluble $\mathrm{Chl}_{a}$-protein from a marine alga whith an extremely high content of $\beta$-pleated 
sheet (27). The similarity of the secondary structure of most Chl-proteins suggests that also the mode of pigment organization may be similar and that the $\mathrm{Chl}$ molecules in the PSII reaction center complex may be arranged between transmembrane helices with the plane of the pigments more or less vertical to the plane of the membrane analogous to the structure of a bacterial reaction center complex (14).

The number of known chloroplast coded gene sequences and thus of deduced amino acid sequences is increasing faster than the number of directly determined chloroplast protein amino acid sequences. As a consequence indirect approaches have to be used to assign functions to the deduced amino acid sequences. The gene for the $51 \mathrm{kD} \mathrm{Chl}{ }_{a}$-apoprotein in spinach was identified using an antibody raised in rabbits against the corresponding Chlamydomonas protein (47). We are now able to confirm this assignment. We have obtained a sequence of 20 amino acids after partial proteolytic digestion of $\mathrm{Chl}_{a}$-protein 2. This sequence is identical in 18 out of 20 positions to that deduced from a portion of the specified spinach nucleotide sequence (29). Moreover the size of the isolated peptides was in agreement with the positions of glutamic and aspartic acid residues predicted from the gene sequence. That the barley sequence is so similar to the deduced spinach sequence and that an antibody raised against Chlamydomonas will precipitate an in vitro translated spinach protein supports our proposal in the introduction that $\mathrm{Chl}_{a}$-protein 2 is conserved to the same extent as the D2 and the $32 \mathrm{kD}$ herbicide-binding polypeptide $(3,13$, $15,22,37,50)$. In this connection it should be mentioned that the isolated peptides were derived from a relatively hydrophilic part of the molecule as judged from the deduced spinach protein sequence. This part of the polypeptide chain is probably not buried in the membrane and therefore not involved in pigment-binding. The function of this part of the protein is unknown, but the high degree of conservation suggests an important role.

\section{ACKNOWLEDGEMENTS}

Professor DITER vON WETTSTEIN is thanked for encouragement throughout the course of this work and for a careful review of this manuscript. It is a pleasure to acknowledge the excellent collaboration with Dr. KAREN G. WELINDER at the Institute of Biochemical Genetics, University of Copenhagen for obtaining the amino acid sequences on the gas-phase sequencer. I am indebted to PENNY VON WETTSTEIN-KNOWLES for analyzing the lipid content of the preparations and for her many helpful suggestions. GAMINI KANNANGARA and DAVID J. SIMPSON are thanked for critically reading the manuscript. IB SVENDSEN, BODIL CORNELIUSSEN and LONE SøRENSEN are thanked for performing the amino acid analyses. I thank TOM BektVed, Ole Hansen, Pia Jensen, Inga OlSen, Merete Petersen, Nina Rasmussen and ANN-SOFI STEINHOLTZ for technical assistance. Amino acid sequence analyses were covered by grant 12-5206 from the Danish Medical Research Council. This work was supported in part by a fellowship of the Schweizer Nationalfonds to URSULA HiNZ.

\section{REFERENCES}

1. ẢKerlund, H. E., C. JANson \& B. Andersson: Reconstitution of photosynthetic water splitting in inside-out thylakoid vesicles and identification of a participating polypeptide. Biochim. Biophys. Acta 681, 1-10 (1982)

2. ANDERSSON, B., C. CRITCHLEY, I. J. RYRIE, C. JANSON,C.LARSSON \& J.M. ANDERSON: Modification of the chloride requirement for photosynthetic $\mathrm{O}_{2}$ evolution. The role of the $23 \mathrm{kD}$ polypeptide. FEBS Lett. 168, 113-117 (1984)

3. Alt, J., J. MORRIS, P. WeSthoff \& R. G. HerRMANN: Nucleotide sequence of the clustered genes for the $44 \mathrm{kD} \mathrm{Chl}_{a}$ apoprotein and the " $32 \mathrm{kD}$ "-like protein of the photosystem II reaction center in the spinach plastid chromosome. Current Genetics 8, 597-606 (1984)

4. ARNON, D. J.: Copper enzymes in isolated chloroplasts. Polyphenoloxidase in Beta vulgaris. Plant Physiol. 24, 1-4 (1949)

5. Avato, P., J. D. Mikkelsen \& P. von WettsteinKNOWLES: Synthesis of epicuticular primary alcohols and intracellular fatty acids by tissue slices from $c e r-j^{59}$ barley leaves. Carlsberg Res. Commun. 47, 377-390 (1982)

6. BASSI, R.,O.MACHOLD\&D.SimPSON: Chlorophyll proteins of two photosystem I preparations from maize. Carlsberg Res. Commun. 50, 145-162 (1985) 
U.G. HINZ: Photosystem II reaction center complex

7. Berthold, D. A., G. T. BABCOCK \&.C. F. Yocum: A highly resolved, oxygen-evolving photosystem II preparation from spinach thylakoid membranes. EPR and electron transport properties. FEBS Lett. 134, 231-234 (1981)

8. BRETON, J.: The $695 \mathrm{~nm}$ fluorescence of chloroplasts at low temperature is emitted from the primary acceptor of photosystem II. FEBS Lett. $147,16-20$ (1982)

9. BRETON, J. \& E. NABEDRYK: Transmembrane orientation of $\alpha$-helices and the organization of chlorophyll in photosynthetic pigment-protein complexes. FEBS Lett. 176, 355-359 (1984)

10. Capaldi, R. A. \& G. VAnderkoor: The low polarity of many membrane proteins. Proc. Acad. Sci. USA 69, 930-932 (1972)

11. Cleveland, D. W., S. G. Fischer, M. W. KIRSCHNER \& U. K. LAEMMLI: Peptide mapping by limited proteolysis in SDS and analysis by gel electrophoresis. J. Biol. Chem. 252,1102-1106 (1977)

12. Cocucci, M. C. \& E. MARre: Lysophosphatidylcholine-activated, vanadate-inhibited, magnesium ATPase from radish microsomes. Biochim. Biophys. Acta 771, 42-52 (1984)

13. Curtis, S. E., \& R. Haselkorn: Isolation, sequence and expression of two members of the 32 $\mathrm{kd}$ thylakoid membrane protein family from the cyanobacterium Anabaena 7120. Plant Mol. Biol. 3, 249-258 (1984)

14. Dosenhofer, J., O. EpP, K. Miki, R. Huber \& H. MICHEL: X-ray structure analysis of a membrane protein complex. Electron density map at $3 \AA$ resolution and a model of the chromophores of the photosynthetic reaction center from Rhodopseudomonas viridis. J. Mol. Biol. 180, 385-398 (1984)

15. ERICKSON, J. M., M. RAhIRE \& J. -D. Rochaix: Chlamydomonas reinhardii gene for the 32.000 mol. wt. protein of photosystem II contains four large introns and is located entirely within the chloroplast inverted repeat. EMBO J. 3, 27532762 (1984)

16. Ghanotakis, D. F., J. N. Topper, G. T. BABCOCK \& C. F. Yocum: Water-soluble 17 and $23 \mathrm{kD}$ polypeptides restore oxygen evolution activity by creating a high-affinity binding site for $\mathrm{Ca}^{2+}$ on the oxidizing side of photosystem II. FEBS Lett. $170,169-173$ (1984)

17. GOUNARIS, K. \& J. BARBER: Isolation and characterization of a photosystem II reaction centre lipoprotein complex. FEBS Lett. 188, 68-72(1985)

18. НАTCH, F. T.: Correlation of amino acid composition with certain characteristics of proteins. $\mathrm{Na}$ ture 206, 777-779 (1965)
19. Heller, J.: Structure of visual pigments. I. Purification, molecular weight and composition of bovine visual pigment. Biochemistry 7, 2906-2913 (1968)

20. Henry, L. E. A. \& B. L. Møller: Polypeptide composition of an oxygen evolving photosystem II vesicle from spinach chloroplasts. Carlsberg Res. Commun. 46, 227-242 (1981)

21. Henry, L. E. A., J. Mikkelsen \& B. L. Møller: Pigment and acyl lipid composition of photosystem I \& II vesicles and of photosynthetic mutants in barley. Carlsberg Res. Commun. 48, 131148 (1983)

22. HolzschuH, K., W. Bottomley \& P. R. WhitFELD: Structure of the spinach chloroplast genes for the D2 and $44 \mathrm{kD}$ reaction center proteins of photosystem II and for tRNA ${ }^{\text {ser }}$ (UGA). Nucleic Acids Res. 12, $8819-8833$ (1984)

23. Jordan, B. R., W. -S. Chow \& A. J. BAKeR: The role of phospholipids in the molecular organization of pea chloroplast membranes. Effect of phospholipid depletion on photosynthetic activities. Biochim. Biophys. Acta 725, 77-86 (1983)

24. LowRY, O. H., N. J. Rosebrough, A. L. FARR \& R. J. RANDALL: Protein measurement with the folin phenol reagent. J. Biol. Chem. 193, 265-279 (1951)

25. Machold, O., D. J. Simpson \& B. L. Møller: Chlorophyll proteins of thylakoids from wild type and mutants of barley (Hordeum vulgare). Carlsberg Res. Commun. 44, 235-254 (1979)

26.MAR, T. \& G. Gingras: An asymmetric dimer exciton model. Application to the primary electron donor of bacterial reaction center. Biochim. Biophys. Acta 764, 283-294 (1984)

27. Matthews, B. W., R. E. Fenna, M. C. Bolognesi, M. F. SCHMID \& J. M. Olson: Structure of a bacteriochlorophyll $a$-protein from the green photosynthetic bacterium Prosthecochloris aestuarii. J. Mol. Biol. 131, 259-285 (1979)

28. Michel. H.: Three-dimensional crystals of a membrane protein complex: The photosynthetic reaction center from Rhodopseudomonas viridis. J. Mol. Biol. 158, 567-572 (1982)

29. Morris, J. \& R. G. HerrmanN: Nucleotide sequence for the $P 680 \mathrm{Chl}_{a}$ apoprotein of the photosystem II reaction center from spinach. Nucleic acids Res. 12, 2837-2850 (1984)

30. MøLLER, B. L.\&P. B.HøJ: A thylakoid polypeptide involved in the reconstitution of photosynthetic oxygen evolution. Carlsberg Res. Commun. 48, 161-185 (1983)

31. NABEDRYK, E., S. ANDRIANAMBININTSOA \& J. BRETON: Transmembrane orientation of $\alpha$-helices in the thylakoid membrane and in the light-har- 
vesting complex. A polarized infrared study. Biochim. Biophys. Acta 765, 380-387 (1984)

32. Nabedryk, E., P. Biaudet, S. DARr, C. J. ARNTZEN \& J. BRETON: Conformation and orientation of Chl-proteins in photosystem I by circular dichroism and polarized infrared spectroscopies. Biochim. Biophys. Acta 767, 640-647 (1984)

33. NAKATANI, H. Y.: Correlation of the low temperature $695 \mathrm{~nm}$ fluorescence emission with the reaction center of photosystem II. In: The Oxygen Evolving System of Photosynthesis. (Y. Inoue, A. R. Crofts, Govindjee, N. Murata, G. Renger \& K. Satoh, eds. ) Academic Press Japan pp. 49-54 (1983)

34. NaKatani, H. Y., E. Dolan \& C. J. ARntzen: Identity of the photosystem II reaction center polypeptide. Biochim. Biophys. Acta 765, 347-352 (1984)

35. NetTING, A. \& C. BARR: Design for an accurate and versatile radio gas chromatograph. Anal. Biochem. 84, 136-146 (1978)

36. Petzel, E. H.\&W. Menke: Conformation analysis of the polypeptides in the thylakoid membrane. Z. Naturforsch. 27b, 585-586 (1972)

37. Rasmussen, O. F., G. Bookjans, B. M. StumMANN \& K. W. HENNINGSEN: Localization and nucleotide sequence of the gene for the membrane polypeptide D2 from pea chloroplast DNA. Plant Mol. Biol. 3, 191-199 (1984)

38. SAтOH, K.: Polypeptide composition of the purified photosystem II pigment protein complex from spinach. Biochim. Biophys. Acta 546, 84-92 (1979)

39. SATOH, K. \& W. L. BUtLeR: Low temperature spectral properties of subchloroplast fractions purified from spinach. Plant Physiol. 61, 373-379 (1978)

40. Schenkman, S., A. Tsugita, M. Schwarz \& J. P ROSENBUSCH: Topology of phage $\lambda$ receptor protein. J. Biol. Chem. 259, $7570-7576$ (1984)

41. Simpson, D. J. \& D. von Wettstein: Macromolecular physiology of plastids. XIV. Viridis mutants in barley: Genetic, fluoroscopic and ultrastructural characterization. Carlsberg Res. Commun. 45, 283-314 (1980)

42. Sternberg, J. C., W. S. Gallaway \& D. T. L. JONES: The mechanism of response of flame ion- ization detectors. In: Proc. Instrument Soc. Amer. 3rd Int. Symp. on Gas Chromatogr. (N. Brenner, J. E. Callen \& M. D. Weiss eds. ) Academic Press, New York, San Francisco and London pp 231-267 (1962)

43. SayARE, M.\&M. Fikiet: Crosslinking of hemoglobin to the cytoplasmic surface of human erythrocyte membranes. Identification of band 3 as a site for hemoglobin binding in copper $\left(2^{+}\right)$-o-phenanthroline catalized crosslinking. J. Biol. Chem. 256, 13152-13158 (1981)

44. TAKegushi, N., R. Joshima, Y. INOUE, T. KashIWAGURA \& M. MORI: Effects of copper(II)-o-phenenthroline on gastric proton-potassium ATPase. Evidence for opening of a closed anion conductance by disulfide crosslinkings. J. Biol. Chem. 258 , 3094-3098 (1983)

45. TANG, X. -S. \& K. SATOH: Characterization of a $47 \mathrm{kD}$ chlorophyll-binding polypeptide (CP-47) isolated from a photosystem II core complex. Plant \& Cell Physiol. 25, 935-945 (1984)

46. TANG, X. -S. \& K. SATOH: The oxygen-evolving photosystem II core complex. FEBS Lett. 179, 60-64 (1985)

47. Westhoff, P., J. Alt \& R. G. HerrmanN: Localization of the genes for the two $\mathrm{Chl}_{a}$-conjugated polypeptides (mol, weight 51 and $44 \mathrm{kD}$ ) of the photosystem II reaction center on the spinach plastid chromosome. EMBO J. 12, 2229-2237 (1983)

48. Wray, W., T. BOUlikas, V. P. WRAY \& R. HANCOCK: Silver staining of proteins in polyacrylamide gels. Anal. Biochem. 118, 197-203 (1983)

49. YUASA, M., T. -A. ONO \& Y. INOUE: Isolation of photosystem II reaction center complex retaining $33 \mathrm{kD}$ protein and $\mathrm{Mn}$, a possible structural minimum of photosynthetic $\mathrm{O}_{2}$-evolving system. Photobiochem. \& Photobiophys. 7, 257-266 (1984)

50. Zurawsky, G., H. J. Bohnert, P. R. Whitfeld \& W. Bottomley: Nucleotide sequence of the gene for the $\mathbf{M}_{\mathbf{r}} 32,000$ thylakoid membrane protein from Spinacia oleracea and Nicotiana debney predicts a totally conserved primary translation product of $M_{r}$ 38,950. Proc. Natl. Acad. Sci. USA 79, 7699-7703 (1982)

Accepted by E. LUND 